JEL: L25, O13, P27, Q13

Valentyna Stadnyk $^{1}$, Galyna Krasovska ${ }^{1}$, Pavlo Izhevskiy, ${ }^{2}$
Tetiana Tomalia ${ }^{1}$, Lilia Khomych ${ }^{1}$, Pavlo Matveev

${ }^{1}$ Khmelnytskyi National University

${ }^{2}$ Leonid Yuzkov Khmelnytskyi University of Management and Law

${ }^{3}$ Kharkiv National Agrarian University named after V. V. Dokuchayev

Ukraine

\title{
MOTIVATIONAL ASPECTS OF DEVELOPMENT OF STRATEGIC NETWORK PARTNERSHIP IN THE AGRO-INDUSTRIAL COMPLEX
}

Purpose. The purpose of this paper was to determine motivational factors of structural changes in the agro-industrial sector of Ukraine, which will strengthen the ability of business entities to generate larger added value flows and increase efficiency through the development of strategic network partnerships.

Methodology / approach. While writing the article the following methods were used: methods of economic and statistical analysis - to study the dynamic of indicators that reflect the results of sectoral structural changes of the enterprises' activities in the sector of agriculture, forestry and fisheries of Ukraine during 2016-2019; critical analysis - to identify shortcomings in the legislative field of Ukraine, which deform motivational vectors, negatively affect the development of agroindustrial complex; morphological analysis and synthesis - to prove the feasibility of interpreting the term "network capital" in a narrow and broad sense; scientific abstraction and graphic visualization - to build the model of formation of network capital and use in the processes of organizational interaction of participants in a strategic business partnership; mathematical modelling - to formalize the conditions under which the network partnership participants will avoid manipulation by the expert environment in the apportionment of the costs and revenues from the implementation of business projects.

Results. It has been studied the dynamic of indicators that reflect the results of the sectoral and structural changes in activities of Ukrainian enterprises in the agriculture, forestry, and fisheries sector during 2016-2019. It has been highlighted shortcomings in the legislative field of Ukraine, which distort the vectors of motivational influence on the development of agro-industrial complex, causing the corruption schemes spread in the decisions and actions of economic agents. The essential content of the term "network capital" in a narrow and broad interpretation has been differentiated and the motivational basis for its increase by the business network participants has been highlighted. The processes of formation and use of network capital in the inter-organizational interaction of participants of strategic business partnership have been modelled. Nash equilibrium theory has been applied to increase the reliability of the position assessment of business network participants in the total costs and revenues apportionment and it has been proved that this forms the motivational basis for long-term cooperation.

Originality / scientific novelty. The author's interpretation of the term "network capital" in a broad and narrow sense with emphasis on motivational aspects of this capital increasing in the agro-industrial business network has been proposed. The model of network capital formation and use in the processes of organizational interaction of participants in a strategic business partnership has been constructed. There have been modelled the conditions under which the participants of the network partnership will avoid manipulation by the expert environment in the apportionment processes of costs and revenues from the business projects implementation, which will improve 


\section{Agricultural and Resource Economics: International Scientific E-Journal}

http://are-journal.com

their motivation to cooperate.

Practical value / implications. The main results of the study can be used for (i) elimination of some gaps in the institutional environment of Ukraine, which distort the motivational vectors of agricultural development; (ii) managing growth processes of network capital to increase the aggregate ability of business network participants to create new consumer value with high added value; (iii) improving the motivational basis for long-term cooperation of business network participants by increasing the reliability of their positions assessment in the total costs and revenues apportionment.

Key words: sustainable development, institutional gaps, sectoral changes, agro-industrial business network, network capital, consumer value, added value, Nash equilibrium, Ukraine.

Introduction and review of literature. The agro-industrial sector plays an important role in the Ukrainian socio-economic development. Firstly, it solves the country food security problem, secondly, it forms a significant share of its export potential, and thirdly, it makes a significant contribution to gross domestic product. At the same time, given the favourable climatic opportunities for agribusiness in Ukraine, such contribution could be much greater. Therefore, a significant number of domestic scientists study the problems and determine the prospects for the industry development.

In particular, in recent years, a lot of research has been conducted in line with the concept of sustainable development, which combines the tasks of economic growth, environmental security and social progress [1-3]. In the agricultural sector, this implies the development of organic farming and "green entrepreneurship", which is emphasized, in particular, by M. Ihnatenko and N. Novak [4], A. Kucher [5], L. Kucher, S. Drokin and Y. Ulko [6], A. Shevchenko and O. Petrenko [7], O. Skydan, O. Nykolyuk, P. Pyvovar and I. Martynchuk [8]. These and other scientists, outlining the problems of agricultural (including organic) production in Ukraine, are focused on the fact that many of them could be avoided if the state took more effective measures to regulate economic activity in the agro-industrial complex. These measures should stimulate agribusiness development in the direction of increasing the level of agricultural product processing and increasing the cost structure of added value. This would upgrowth the number of workplaces, raise incomes and improve the quality of life of the rural population, and also preserve the environment for future generations, in line with the concept of "sustainable development". For Ukraine, the solution of these problems is one of the priorities, this confirms the relevance of the stated research topic, both on the identification of motivational factors for their implementation, and the selection of organizational forms of the agribusiness development adequate to the modern challenges, in particular, the creation of business networks.

Motivational factors of building and participating in strategic business networks in the modern economic literature are considered both from the standpoint of the state and society, and participating companies. Special attention is paid to this in publications of the authors who examine various sectoral cooperation in the agroindustrial complex. 


\section{Agricultural and Resource Economics: International Scientific E-Journal}

http://are-journal.com

In particular, in the work "Securing the future of US agriculture: The case for investing in new entry sustainable farmers" [9], it is considered the problem of entry into the agricultural sector of newcomers who face barriers of critical access to assets, land, capital, markets, equipment, labour, training and technical assistance needed to succeed. The possibility of overcoming these problems with the participation of the state in the partial financing of projects to create a business network in the form of agricultural cooperatives is indicated. In our opinion, such an approach has a selective motivational effect, as it will motivate only one project. Moreover, it is not free from subjectivity of people who make decisions in state management structures and the lack of clear criteria for project selection may carry risks of corruption.

Another option for using motivational factors to involve partners in strategic participation in business networks is offered by J. Cardoso, F. Casarotto and C. Marcon [10]. They determine the motivational basis of network cooperation in the form of a common goal and competitive income from interaction between partners. The authors describe organizational strategies and management tools that ensure the effectiveness of networks of small organic farming enterprises, based on the networking general principles. However, they consider organizational interaction only in the context of performing the functions assigned to network members, without delving into the study of the reasons that may impair the motivational basis of the strategic partnership.

Interesting in terms of expanding the scope of motivational influence on potential participants in strategic network partnerships is the research of M. Savarese, K. Chamberlain and G. Gragna [11]. Their work central element is the research of the practice of community support for the activities of farms that conduct their business on the sustainable development principles. The motives for creating such a business network are to change the food consumption classic model to the active participation concept of consumers as economic, social and environmental values guardians. This forms a new ideology of cooperation with producers based on the creation of common value for development because at the same time the interests of the farmers and consumers of their products are satisfied. Such cooperation is beneficial for everyone, motivating local producers, consumers and the community as a whole to participate in the business network along the consumer value chain. However, its motivational reinforcement is local in nature and applies mainly to small-scale development projects.

An important motivational element of enterprises effective cooperation in the business networks of agricultural sector is the creation of business value. According to V. Sadovska, L. Axelson, and C. Mark-Herbert this ensures the sustainability of the business in the market [12]. Researchers have identified the need to rethink value creation in agriculture and related industries to implement a development strategy. This process should be based on innovation, knowledge acquisition and cooperation with external stakeholders. In business networks, this is facilitated by nine factors opportunities for collaboration, communication, knowledge, production, diversification, entrepreneurship, financing, policy and inclusion, which are evaluated 


\section{Agricultural and Resource Economics: International Scientific E-Journal http://are-journal.com}

by financial, environmental and social measuring instruments. As the authors rightly point out, the benefit of farmers from participating in business networks is the ability to form a long-term development strategy as opposed to the traditional strategies of enterprises in the industry, which are to reach a "short-term point".

Domestic scientists also pay considerable attention to the strategic prospects for the development of agricultural production in the form of network business partnerships. In particular, Yu. Pasichnyk studies these processes from the standpoint of expanding the export potential of the Ukrainian economy [13]. He rightly points out that the main obstacle for increasing export of agricultural products is their raw material nature. The main thesis of this research is to emphasize the need to expand the production of ready-to-eat foods. This is in the interests of agricultural producers, who will be able to increase the efficiency of the available resources use for opening new activity areas. At the same time, it is beneficial for the state due to the jobs number growth and the budget revenues increase at all levels. Of course, the arguments presented by $\mathrm{Yu}$. Pasichnyk are into the motives list for the development of strategic partnerships in agricultural business networks, which may include enterprises in related industries. We believe that such a partnership also brings social benefits to Ukraine, as the new jobs creation makes it possible to reduce the workers abroad outflow, which is growing every year and may become catastrophic for the national economy. However, in this work, purely motivational levers are not paid attention neither by the state nor within the strategic partnership. In particular, there are no specific recommendations for improving the motivational basis for partnerships between participants in agricultural business networks, although their motivational preferences may change over time and this will affect the cooperation effectiveness.

One of the options to improve the conditions of cooperation in agro-industrial business networks, we proposed in a previous paper, modelling options for implementing competitive strategies in the field of "green entrepreneurship" [14]. Also, the strategic priorities of such agricultural enterprises' cooperation were considered by us in [15] the context of the development of Ukrainian industrial sector. However, we focused on expanding the innovation and investment opportunities of business network members, only briefly pointing out that these opportunities may increase due to preferential lending rates of joint business structures.

Thus, the analysis of recent research on the development of strategic network partnerships in the agricultural production field has shown that scientists focus more on the functional factors of such interaction, ignoring the specifics of motivational processes in today's business environment. Obviously, it should be systemic in nature, combining external and internal motivational influences on participants in the processes of creating consumer values and directing the motivational vector in line with the concept of sustainable development. The relevance of this problem for the enterprises of the agro-industrial sector of the Ukrainian economy has determined the purpose and objectives of our study. 


\section{Agricultural and Resource Economics: International Scientific E-Journal}

http://are-journal.com

The purpose of the article was to determine motivational factors of structural changes in the agro-industrial sector of Ukraine, which will strengthen the ability of business entities to generate larger added value flows and increase efficiency through the development of strategic network partnerships.

The objectives of the article were: (i) analysis of trends in the development of entrepreneurship in the agricultural production field in Ukraine, their correlation with the sustainable development goals and identification of motivational factors that determine its sectoral changes; (ii) substantiation of development expediency of the agribusiness integrated organizational forms on the basis of increasing concept of the network capital; (iii) development of recommendations for improving motivational basis of the strategic network partnership in the agro-industrial complex of Ukraine.

Methodology. The dynamics of indicators that reflect the results of sectoral structural changes of the enterprises' activities in the sector of agriculture, forestry and fisheries of Ukraine during 2016-2019 have been studied by methods of economic and statistical analysis. With the critical analysis methods, it has been identified shortcomings in the legislative field of Ukraine, which deform motivational vectors, negatively affect the Ukraine agro-industrial complex development and cause the spread of corruption schemes in the decisions and actions of economic agents. The essential content of the term "network capital" in a narrow and broad interpretation has been differentiated and its motivational bases have been distinguished by morphological analysis and synthesis methods. A logical model of network capital formation and use in the processes of participants' organizational interaction in a strategic business partnership has been built by methods of scientific abstraction and graphic visualization. The method of mathematical modelling has been used to formalize the conditions under which the participants of the network partnership will avoid manipulation by the expert environment in the distribution of costs and revenues from the implementation of business projects.

Results and discussions. Important tasks of the structural transformation of national economy are the development of those sectors which resource and market potential can provide a tangible positive impact on the overall economic dynamics. Among them is the agro-industrial sector, which in Ukraine is developing quite strongly, increasing the volume of production every year (Fig. 1). It carries out a large number of economic activities by the enterprises of various organizational and legal forms and scales. These are both large agricultural holdings and medium-sized agricultural companies, small farms, and micro-enterprises with only a few people stuff. Each of them develops its strategy of behaviour in the market, striving to gain a foothold and dominate it. This is especially true for large agricultural holdings that specialize in growing and exporting industrial and grain crops. This strategy provides them with significant income and the opportunity to expand their market presence. It is obvious that as the scale of activity increases, they should increase their contribution to total production.

However, the graphs show that with the constant growth of agricultural production during 2013-2019, the contribution of large enterprises to the total 
industry since 2015 was decreasing and fell to $8,8 \%$ in 2017 , that was $-1,9$ times. In the following years, this indicator gained positive dynamics and in 2019 amounted to $12.7 \%$. Taking into account that in 2015 there was still fighting in eastern Ukraine and this had a significant impact on the activities of large agricultural holdings, it is advisable not to take this year into account for further analysis. And though in 20162017 the negative trend in the activities of enterprises in this sector continued, in the following years it was overcome - the large enterprises' products share increased from 8,8 to $12.7 \%$.

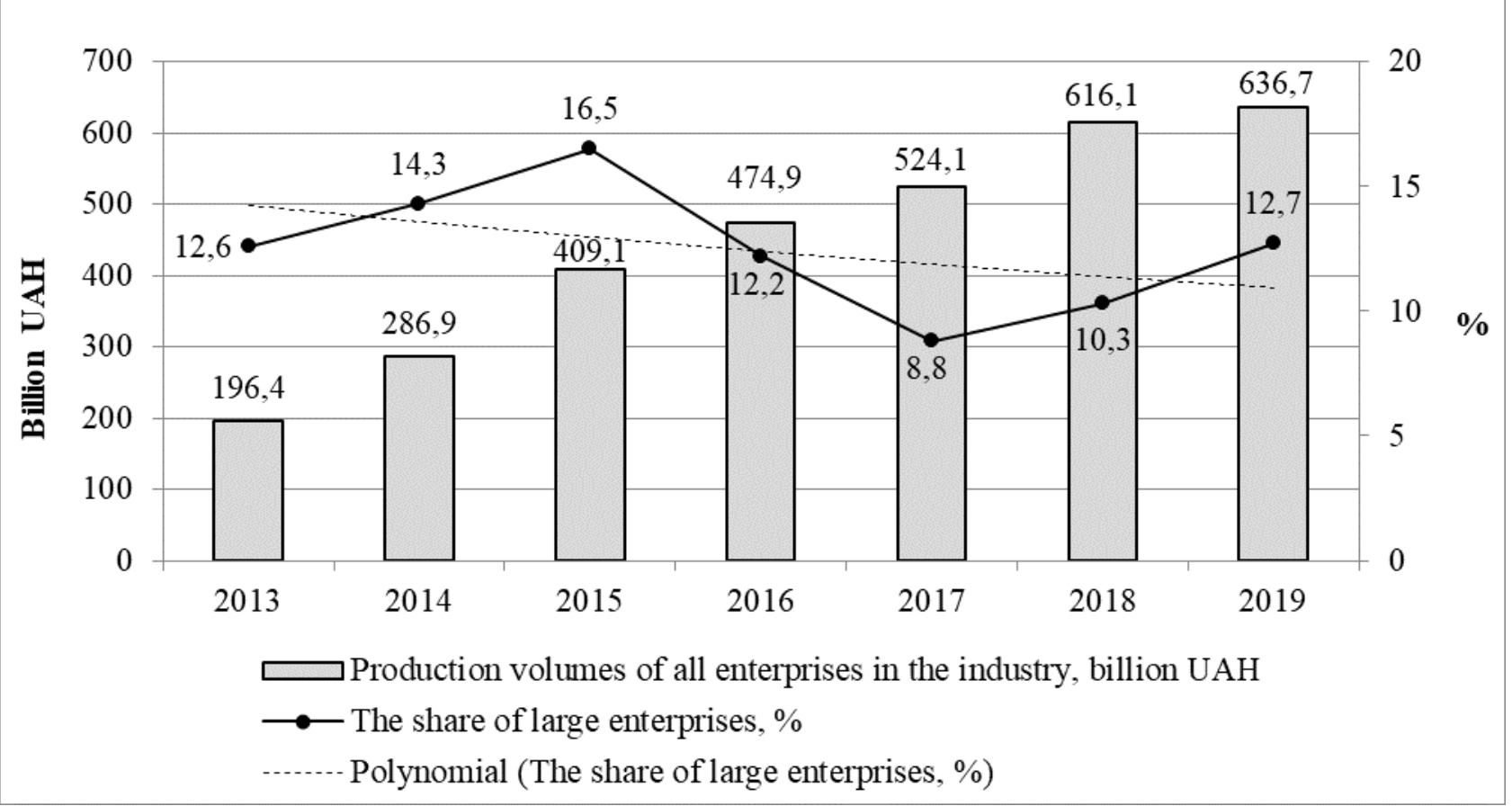

Fig. 1. Dynamics of contribution of large enterprises to the general production results of agricultural, forestry and fisheries enterprises in Ukraine

Source: formed by the authors on the basis of the State Statistics Service of Ukraine [16].

The main reason for the sharp decline of the large enterprises' contribution to the agricultural production is the abolition of the special Value added tax regime, which took place in 2 stages - in 2016 the producer still had a share of Value added tax (its size depended on the industry and the smallest was for technical crops $15 \%$ ), and from 01.01.2017 the special regime was abolished at all. Enterprises could pay taxes under the general system or choose a simplified system of taxation in the form of a single tax of group IV. This led to a certain "reformatting" of large enterprises, part of the business transfer to a sector with a simplified system of taxation. And if in 2015 there were 29 large agricultural enterprises, in 2016 their number decreased to 20 , in 2017 - to 18 . And only in subsequent years began grows to 23 enterprises in 2018 and 34 - in 2019 [17].

Given these changes in government regulation of the industry (to which large enterprises have found a way to adapt, as their share in production has almost returned to the level preceding the changes), we consider it appropriate to carry out a comparative structural analysis of the industry in 2016 and 2019 years. The corresponding data are given in Table 1 . 


\section{Structural indicators of Ukrainian enterprises' activity in the agriculture, forestry and fisheries sector}

\begin{tabular}{|c|c|c|c|c|c|}
\hline \multirow{3}{*}{ Indicators } & \multirow{3}{*}{$\begin{array}{c}\text { All } \\
\text { enterprises }\end{array}$} & \multicolumn{4}{|c|}{$\begin{array}{c}\text { Types of enterprises according to their } \\
\text { size }\end{array}$} \\
\hline & & \multirow{2}{*}{ large } & \multirow{2}{*}{ middle } & \multicolumn{2}{|c|}{ small } \\
\hline & & & & all & incl. micro \\
\hline \multirow{2}{*}{$\begin{array}{l}\text { Total volume of production, billion UAH } \\
(2016 / 2019)^{*}\end{array}$} & $\underline{474.9}$ & $\underline{57.7}$ & $\underline{245.5}$ & $\underline{171.6}$ & $\underline{60.4}$ \\
\hline & $\overline{636.7}$ & $\overline{81.0}$ & $\overline{312.7}$ & $\overline{243.0}$ & $\overline{89.7}$ \\
\hline \multirow{2}{*}{$\begin{array}{l}\text { Share of manufactured products by size of } \\
\text { enterprises, \% }(2016 / 2019)^{*}\end{array}$} & $\underline{100}$ & $\underline{12.4}$ & $\underline{52.8}$ & $\underline{34.8}$ & $\underline{11}$ \\
\hline & 100 & 12.7 & 49.1 & 38.2 & 14.1 \\
\hline $\begin{array}{l}\text { The rate of change in production volumes, } \\
\%(2019 / 2016)\end{array}$ & 134.1 & 140.4 & 127.3 & 141.6 & 148.5 \\
\hline $\begin{array}{l}\text { Change in the share of manufactured } \\
\text { products, } \%(2019 / 2016)\end{array}$ & $\mathrm{x}$ & +0.3 & -3.7 & +3.4 & +3.1 \\
\hline \multirow{2}{*}{$\begin{array}{l}\text { Number of enterprises engaged in } \\
\text { economic activities, units }(2016 / 2019) *\end{array}$} & $\underline{44998}$ & $\underline{20}$ & 2501 & 42477 & $\underline{37457}$ \\
\hline & $\overline{50239}$ & $\overline{34}$ & $\overline{2281}$ & $\overline{47924}$ & $\overline{42633}$ \\
\hline \multirow{2}{*}{ Share in total, \% (2016/2019)* } & $\underline{100}$ & $\underline{0.1}$ & $\underline{5.6}$ & 94.4 & $\underline{83.2}$ \\
\hline & $\overline{100}$ & $\overline{0.1}$ & $\overline{4.5}$ & $\overline{95.4}$ & $\overline{84.9}$ \\
\hline $\begin{array}{l}\text { The rate of change of enterprises number, } \\
\%(2019 / 2016)\end{array}$ & 111.6 & 170.0 & 91.2 & 112.8 & 113.8 \\
\hline \multirow{2}{*}{$\begin{array}{l}\text { Production volume per one enterprise, mln } \\
\text { UAH }(2016 / 2019)^{*}\end{array}$} & $\underline{10.6}$ & $\underline{2885.0}$ & $\underline{98.2}$ & $\underline{4.0}$ & $\underline{1.6}$ \\
\hline & 12.7 & 2382.4 & $\overline{137.1}$ & $\overline{5.1}$ & $\overline{2.1}$ \\
\hline $\begin{array}{l}\text { rate of change of the indicator } \\
(2019 / 2016), \%\end{array}$ & 120.1 & 82.6 & 139.6 & 125.5 & 130.5 \\
\hline \multirow{2}{*}{$\begin{array}{l}\text { Added value at cost of production, billions } \\
\text { UAH }(2016 / 2019)^{*}\end{array}$} & 186.9 & $\underline{19.8}$ & 96.6 & 70.5 & $\underline{21.9}$ \\
\hline & 211.4 & 9.9 & 115.6 & 85.9 & 34.1 \\
\hline $\begin{array}{l}\text { rate of change of the indicator } \\
(2019 / 2016), \%\end{array}$ & 113.1 & 50.0 & 119.7 & 121.8 & 155.7 \\
\hline \multirow{2}{*}{$\begin{array}{l}\text { Added value per } 1 \text { UAH of manufactured } \\
\text { goods, UAH/UAH }(2016 / 2019)^{*}\end{array}$} & $\underline{0.39}$ & $\underline{0.34}$ & $\underline{0.39}$ & $\underline{0.41}$ & $\underline{0.36}$ \\
\hline & 0.33 & 0.12 & 0.37 & 0.35 & 0.38 \\
\hline $\begin{array}{l}\text { rate of change of the indicator, \% } \\
(2019 / 2016)^{*}\end{array}$ & 84.37 & 35.62 & 93.99 & 86.04 & 104.85 \\
\hline
\end{tabular}

* Note: numerator -2016 year; denominator -2019 year.

Source: calculated by the authors on the basis of the State Statistics Service of Ukraine [16$18]$.

The above data show that in 2019 in the field of agricultural production the volume of products produced by large enterprises was increased compared to 2016 by $40.4 \%$, and their share in total (see Table 1) during this time increased only slightly (from 12.4 to $12.7 \%$ ); at the same time, the number of large enterprises was increased 1.7 times (34 against 20 in 2016). At the same time, in the medium-sized business sector, quantitative changes were of a different nature - with a $27.3 \%$ increase in production, their share was decreased only 3.7 percentage points, and the number of enterprises was decreased by $8.8 \%$ (220 units).

A simple comparison of these changes indicates that in agricultural sector of Ukraine in 2019 there were created more favorable conditions for business growth. Although the consolidation could take place only nominally - due to the changes in 
the legal status of some enterprises that were part of agricultural holdings but formed separate accounting to optimize taxation terms. Declared by the Ukrainian government struggle to bring out such "optimization schemes" of the shadows made them too risky and forced business owners to disclose the true scale of their activities. This automatically turned such agricultural enterprises into large ones and even prompted 9 public agricultural companies to place their shares on stock exchanges 7 on the Warsaw Stock Exchange and 2 on the London Stock Exchange. And the favorable situation on the agricultural products market in 2020 provided a significant capitalization of these companies. According to the press service of the "Ukrainian Club of Agrarian Business" [19], the shares of Ukrainian agricultural companies in October 2020 were increased by an average of $10 \%$. The total capitalization from October to November was increased by $10.8 \%$ (191.5 USD million) and amounted to 1.93 USD billion as of November 12, 2020 (Table 2).

Table 2

\section{Growth of market value of some Ukrainian agricultural companies} (November / October 2020)

\begin{tabular}{|l|c|c|}
\hline \multicolumn{1}{|c|}{ Company name } & Growth, \% & $\begin{array}{c}\text { Market value of the company on } \\
12.11 .2020, \text { million USD }\end{array}$ \\
\hline Astarta & 33.3 & 156.0 \\
\hline Myronivski khliboprodukty & 9.8 & 650.1 \\
\hline Kernel & 9.24 & 906.7 \\
\hline Industrialna molochna kompania & 7.77 & 107.8 \\
\hline Ovostar & 7.75 & 108.4 \\
\hline
\end{tabular}

Source: formed by the authors on the basis [19].

In general, business growth in agricultural sector of Ukraine also includes mergers and acquisitions - they occur in any business environment. And such trends are useful because they help strengthen the strategic perspective of business market position. However, from the standpoint of the sustainable development goals of national economy, it is important to assess their effectiveness and take into account social benefits - how it affects the social and environmental component of the life quality of present and future generations.

Such an assessment can be made, in particular, through indicators of added value. The processes are positive, when their results provide an increase in added value - because in total staff costs are dominant (and these are jobs with the appropriate level of wages). However, our calculations (see Table 1) showed that added value at the cost of production in the aggregate of large enterprises has halved. It could be assumed that this is the result of better technical equipment of large enterprises, which reduces the need for labour. However, during this period, the volume of production per enterprise was decreased from 2,883 million UAH to 2,382 million UAH (that was at $17.4 \%$ ). At the same time, in the aggregate of medium-sized enterprises, the dynamics were more positive - the productivity of production by one enterprise was increased by $39.6 \%$, and the volume of added value by almost $20 \%$.

Such trends of structural changes in agricultural production can be explained by 
the fact that large farms specialize in growing technical monocultures for their further export with a minimum level of processing. And this approach to doing business causes an increase in negative trends in this area - because there is a depletion of land, reducing its yield. According to recent studies, as a result of the activities of the agricultural holding, the share of crops that deplete the soil has now reached $51.08 \%$ of the total sown area in Ukraine [20, p. 16].

As a result, the share of agricultural products in total production of Ukrainian enterprises is declining - in 2016 it was $11.3 \%$ (474.9 : 4217.8), and in 2019 - only $9.1 \%(636.7: 6981.9)$ (calculations based on [16]). And this despite the fact that agricultural production for Ukraine is one of the strategic directions of economic development - given the natural and climatic conditions and the significant potential of land resources. However, such development should provide solutions not only to the economy but also to social and environmental problems of society. Because of this, it was considered appropriate to assess the contribution of each agricultural production sector in solving social problems, in particular, the employment and income of the rural population. The corresponding indicators calculated by us on the basis of official statistical reporting are given in Table 3.

Table 3

Structural indicators reflecting the personnel use at agricultural enterprises of Ukraine (2019)

\begin{tabular}{|c|c|c|c|c|c|}
\hline \multirow{3}{*}{ Indicators } & \multirow{3}{*}{$\begin{array}{c}\text { All } \\
\text { enterprises }\end{array}$} & \multicolumn{4}{|c|}{ Types of enterprises by size } \\
\hline & & \multirow{2}{*}{ large } & \multirow{2}{*}{ medium } & \multicolumn{2}{|c|}{ small } \\
\hline & & & & all & incl. micro \\
\hline Labor costs, UAH billion & 51.8 & 6.8 & 31.9 & 13.2 & 3.4 \\
\hline Share by size of enterprises, $\%$ & 100 & 13.1 & 61.5 & 25.4 & 6.6 \\
\hline Number of employees, thousand people & 566.7 & 43.1 & 301.7 & 221.9 & 98.9 \\
\hline Share in total, $\%$ & 100 & 7.6 & 53.2 & 39.2 & 17.4 \\
\hline Share of labour costs in added value, $\%$ & 24.50 & 68.69 & 27.60 & 15.37 & 9.97 \\
\hline $\begin{array}{l}\text { Average number of employees employed } \\
\text { at one enterprise, persons }\end{array}$ & 13 & 2155 & 121 & 5 & 3 \\
\hline $\begin{array}{l}\text { Average monthly salary of one } \\
\text { employee, UAH }\end{array}$ & 7617.20 & 13147.72 & 8811.18 & 4957.19 & 2864.85 \\
\hline $\begin{array}{l}\text { Production volume per employee, } \\
\text { thousand UAH }\end{array}$ & 1095.11 & 1879.35 & 1036.13 & 1022.98 & 557.13 \\
\hline
\end{tabular}
$21 ; 22]$.

Source: calculated by the authors on the basis of the State Statistics Service of Ukraine [17;

Figures show that in 2019, large agricultural enterprises employed only $7.6 \%$ of the total number of agricultural workers, and the share of labour costs was $13.1 \%$. This indicates, firstly, a higher level of salary in this sector compared to others. Indeed, the excess of the average monthly earnings of employees of large enterprises relative to medium-sized employees was 1.5 times (13147.72:8811.18), and small even 2.67 times (13147.72: 4957.19). On the other hand, calculations of output per employee show that labour productivity in the large agribusiness sector is almost 1.8 times higher than in medium and small businesses.

Undoubtedly, the main reason is the better technical equipment of agricultural 
holdings and the advantages of mass production. But then this should be reflected in the structure of added value by production costs - a larger share should be depreciation costs. However, our calculations show that the share of labour costs in the added value of large enterprises is the largest - almost $68.7 \%$. This is 2.5 times more than accumulated by medium-sized enterprises $(27.60 \%)$ and 4.5 times - by small $(15.37 \%)$, although the ratio of wages (see above) is not so significant.

This disproportion in the formation of added value by production costs is difficult to explain. However, if we take into account the impact of the activity scale (10 largest agricultural holdings in Ukraine have 2.66 million hectares of agricultural land), as well as the high productivity of agricultural machinery, the picture becomes clearer. Therefore, the amount of added value per $1 \mathrm{UAH}$ of output in a large business is the lowest $-0.12 \mathrm{UAH} / \mathrm{UAH}$ against three times higher for other sectors. In addition, it continues declining - in 2019 it amounted to only $35.6 \%$ of the 2016 level, in other sectors the decline also occurred, but within 10-15\% (see Table 1).

If we evaluate these trends from the standpoint of the producers' interests, they are natural, because productivity growth is the basis for increasing any business profitability. At the same time, such a low level of added value in the production of large agricultural enterprises with the highest level of wages in it and high technical equipment of production indicates the existence of so-called "optimization" schemes that minimize added value tax. This reduces the public benefit from the quantitative growth of agricultural production in its current form and requires more effective measures of state regulation in agribusiness.

Some positive changes in this area can be expected from the promulgation of the Law of Ukraine "On Amendments to the Tax Code of Ukraine Concerning the Added Value Tax Rate on Transactions for the Supply of Certain Types of Agricultural Products” № 1115-IX, adopted by the Verkhovna Rada of Ukraine on December 17, 2020 [23]. The document came into force on March 1, 2021 and provides for a reduction in the VAT rate from $20 \%$ to $14 \%$ on the supply and import of certain types of agricultural products (whole milk, cereals and oilseeds, cattle, etc.). According to legislators, this will reduce the taxpayers' motivation to optimize VAT liabilities in transactions with these products, and thus - will contribute to the deshadowing of large agricultural producers and agricultural traders (because they specialize in such transactions).

At the same time, it is expected that such changes in taxation will increase the investment inflow to the processing industries development, and thus - will contribute to new jobs creation. And then the motivation of agricultural holdings to export unprocessed raw materials will decrease (VAT refunds will be lower) [24]. However, this motivation will not be enough to diversify production, the gradual transition from growing monocultures to a balanced structure of the product line land use, which would provide the necessary order of crop rotation. And from the sustainable development priorities and food security of Ukraine standpoint, the agricultural sector should be developed in such a way as not only to increase the share of products that can be processed in Ukraine, but also to increase the 


\section{Agricultural and Resource Economics: International Scientific E-Journal}

http://are-journal.com

agricultural production diversification, which will increase its export potential.

And the main role in such structural changes can be played by small and medium-sized businesses, engaged in the production of so-called "niche" and environmentally friendly crops, the demand for which is growing steadily around the world. Their primary industrial processing within such farms (for example, deep freezing) will allow them to enter EU markets, by passing the quotas set by the association agreement. After all, they limit export volume of raw materials, but do not apply to products that undergone industrial processing.

And such processing involves the creation of new jobs (in rural areas). That is, along with the growth of added value and export opportunities for agricultural production, the level of human well-being will increase and social development problems will be solved, this can reduce the outflow of the rural population and stop the villages degradation. Moreover, the measures on state support for the farming and animal husbandry development, which had been carried out in 2018-2019, gave results - the number of agricultural producers in the small business sector was increased significantly, and production and added value was increased by $25.5 \%$ and $21.8 \%$. Similar indicators of medium-sized enterprises were also increased (by 39.6 and $19.7 \%$ ), while those of large enterprises were decreased significantly to 82.6 and $50.0 \%$, respectively (see Table 1 ).

More favorable conditions for this transformation are expected with the development of the land market, which will consolidate the property right, thereby motivating owners to make better use of it from the strategic perspective. This means investing in the development of berry growing (plantation), horticulture or viticulture, orderly land use with crop rotation and land reclamation, the use of new technologies for tillage and plant protection, etc., and thus - the development of livestock and processed products.

However, today medium and small businesses in agriculture do not have enough resources for such development. After all, due to the dispersion of farms, they can't defend their interests before the so-called "aggregators" - those participants in the agro-market who collect products from small producers for resale, setting purchase prices actually at the limit of cost.

It should be noted that mentioned above changes in VAT taxation will have a negative impact on small agricultural producers. For example, due to $6 \%$ reduction in the VAT rate on the supply of milk processing enterprises when purchasing milk from farmers and individual households, traders will have grounds for a corresponding reduction in purchase prices. And this applies to producers of all those types of agricultural products covered by the new law. Because of differences in VAT rates, a cash tax gap will be created for the supply and sale of such products. This will reduce current assets of farmers and will act as a disincentive to the development of agribusiness. And even more - will threaten the bankruptcy of those companies that carry out the primary processing of such products. In particular, as noted by observers of the agricultural market, small flour mills may be facing the threat of bankruptcy due to increased exports of flour from Turkey, because by 


\section{Agricultural and Resource Economics: International Scientific E-Journal}

http://are-journal.com

reducing the VAT rate to $14 \%$ this flour will be cheaper than Ukrainian [24].

Only those who are both producers and processors of such products (at least $50 \%$ ) will have benefits. However, to create their own processing plants it is necessary to purchase the appropriate equipment and technologies, VAT on which remains at $20 \%$. As a result, the tax credit may exceed the number of tax liabilities, which will necessitate the need to reimburse such a gap from the state budget. This is currently happening with significant delays. These and other institutional gaps in Ukrainian tax legislation hinder the implementation of investment processes in the agro-industrial sector.

The creation of agro-industrial business networks may be the way out of this situation. After all, in the industrial sector, small business is looking for development of opportunities and needs appropriate resources. And supporting the development of cooperation network forms is currently a crucial task of the state. Some actions in this direction are planned within the framework of the Resolution "On approval of the National Economic Strategy for the period up to 2030" adopted by the Cabinet of Ministers of Ukraine in March 2021 [25], where among the development strategic goals the formation of an effective organizational model of clusters is provided. Unfortunately, these goals are not supported by specific programs and financial resources, which transforms their implementation into a mode of self-organization. However, today these processes in Ukraine are successfully developing without any state support. In particular, advisory public organizations and associations aimed at building agro-industrial clusters are working successfully: NGO "Ahentcia stalogo Rozvytku ASTAR" (Sustainable Development Agency ASTAR) [26]; NGO "Ukrainska Horikhova Asotsiatsiia" (Ukrainian Nut Association) [27]; "Asotsiatsiia Yahidnytstvo Ukrainy" (Association for Berry growing in Ukraine) [28]; The first national agrarian cooperative [29]) and other.

It should be noted that with the new technologies for growing, storage and industrial processing of agricultural products, the opportunities for productive cooperation of all participants in the chain of consumer values are significantly expanding. And it's not just increasing the investment opportunities of business network participants. It is equally important to integrate efforts to promote finished foods in consumer markets. And it can be not only cooperation in the field of marketing, which considered in [30] but much wider cooperation, which enables to form the total intellectual capital of the business network (network capital).

In scientific sources, network capital is considered as "a set of intellectual property of the organization, processes, methods, implementation procedures used in its activities (that is, network resources created by owners and other stakeholders and used to build elements of internal structure and trust)" [31]. E. Wallace emphasizes that this is "a value created by people through some of the most important relationships in their business connections" [32]. In this author's interpretation, the definition of "network capital" is almost identical in meaning to the definition of "social capital", which P. Bourdieu introduced into the scientific discussion, defining it as a set of social relations that allow individuals to have access to resources that 


\section{Agricultural and Resource Economics: International Scientific E-Journal}

http://are-journal.com

other individuals have [33]. Later, J. Coleman singled out the key condition under which the social capital is formed - mutual trust between participants in social relations and the establishment of certain social norms on which their obligations and expectations are based [34].

In the business environment, social capital increases the opportunities to obtain economic benefits, as emphasized, for example, by A. Kolot [35]. It is this attribute of social capital that acquires special significance under the context of the formation and functioning of business networks, which by their nature are significantly different from social ones. Unlike the social network, the business network has a rather narrow and reasonable circle of participants who unite with a clearly defined business goal solely based on profitable activities. Therefore, we consider legitimate and support the views of those scholars who distinguish the definition of "network capital" concerning business networks. After all, as an asset that can generate income, it is the basis for the creation of business networks that combine the assets of participants under the condition of $1+1>2$ and thus determine the expanded opportunities for themselves to receive benefits (profits) on an institutional basis.

At the same time, R. Camagni emphasizes that this capital is the result of "bilateral and multilateral relations with partners of the internal and external environment of the enterprise in the market, accompanied by an atmosphere of cooperation and trust and formed by inter-organizational culture, common patterns of behaviour and values" [36]. As we can see, scientists emphasize that the formation and development of network capital (as well as social) are possible under the condition of cooperation and trust between network participants. Namely, this trust makes it possible to create new knowledge and new consumer values based on it. However, in the business network, it is possible to manage purposefully the development of social relations capital - in a direction that will maximize the overall economic result. This means that it will increase the benefits of individual network members as well. The contours of these relations development in the network can be both institutional (system of internal implicit norms and obligations, which forms the culture of organizational interaction of network members) and contractual, with clearly defined parameters of cooperation.

Given the fundamental differences in the formation of the characteristics of network capital stated by scientists, we believe it appropriate to consider this term in a broad and narrow sense; in a broad sense as a set of tangible and intangible benefits defined in qualitative and quantitative indicators obtained from the business network; in the narrow sense as a set of relations with enterprises interested in cooperation, formed on an institutional and contractual basis. This allows the initiators of a business network to determine, firstly, the main criteria by which to select participants (maximum contribution to the creation of consumer values), and secondly, how to achieve the effectiveness of their network interaction (forming a motivational basis for mutually beneficial relations).

The use of network capital to create consumer values involves different by content and form acts of inter-organizational interaction of partners. Their 
effectiveness depends on the quality of information exchange, therefore on the trust and stability of relations between partners due to the high level of their commitment to the criteria and values system laid down in the business network [37]. In this case, each of them must be willing to compromise in the satisfaction of their interests to maximize the overall benefit, as emphasized by J. Coleman (1988), characterizing social capital [34]. We consider this characteristic to be decisive for network capital because it creates the conditions for a strategic partnership that can be organizationally stable in the long run. In this case, each of them must be willing to compromise in their interests' satisfaction to maximize the overall benefit, as J. Coleman (1988) emphasized, characterizing social capital [34]. We consider this characteristic to be decisive for the network capital - because it creates the conditions for a strategic partnership that can be organizationally stable in the long run.

To develop a strategy of networking, participants should model future partnerships. To do this, it is recommended to consider each participant as an actor entering a partnership, as well as the goals and forms of such relationships, which each of them claims and perceives as acceptable for himself [38, pp. 217-249]. Such partnership will be optimal (in form and common goals), in which each of the partners sees the benefits for himself, which he would not have out of this network. Hence, the starting point for modelling the partnership terms should be the analysis and identification of the stakeholders' structure needs, which should be considered from the standpoint of their compliance with the relationship objectives. That is, each of the potential participants in the partnership has to understand the other actors' goals, be ready to optimize business processes from the standpoint of these actors' expectations and see opportunities to implement joint measures to maximize consumer value and network capital increase.

The graphical model for realization of network interaction of participants of strategic partnership covers five interconnected blocks - orientation on the network interaction, network capital, obtaining knowledge and information, creation of value and advantage for business (Fig. 2).

The links between these blocks for the potential participants of strategic partnership have the following motivational basis:

- "I" - networking generates new opportunities for value creation;

- "II" - partnership interaction in the network strengthens the participants' ability to respond adequately to the external environment challenges;

- "III" - long-term partnerships in the network form a network capital which sharing through the active information exchange between participants contributes to capacity building of new knowledge potential which is important for higher consumer value creation;

- "IV" - partnership provides participants' resource and market synergy, which contributes to their competitiveness strengthening, sustainable development and business quantitative growth;

- "V" - preferences for network interaction in the processes of resource exchange before market transactions increase the benefits for business in the field of 
investment projects for new consumer values creation.

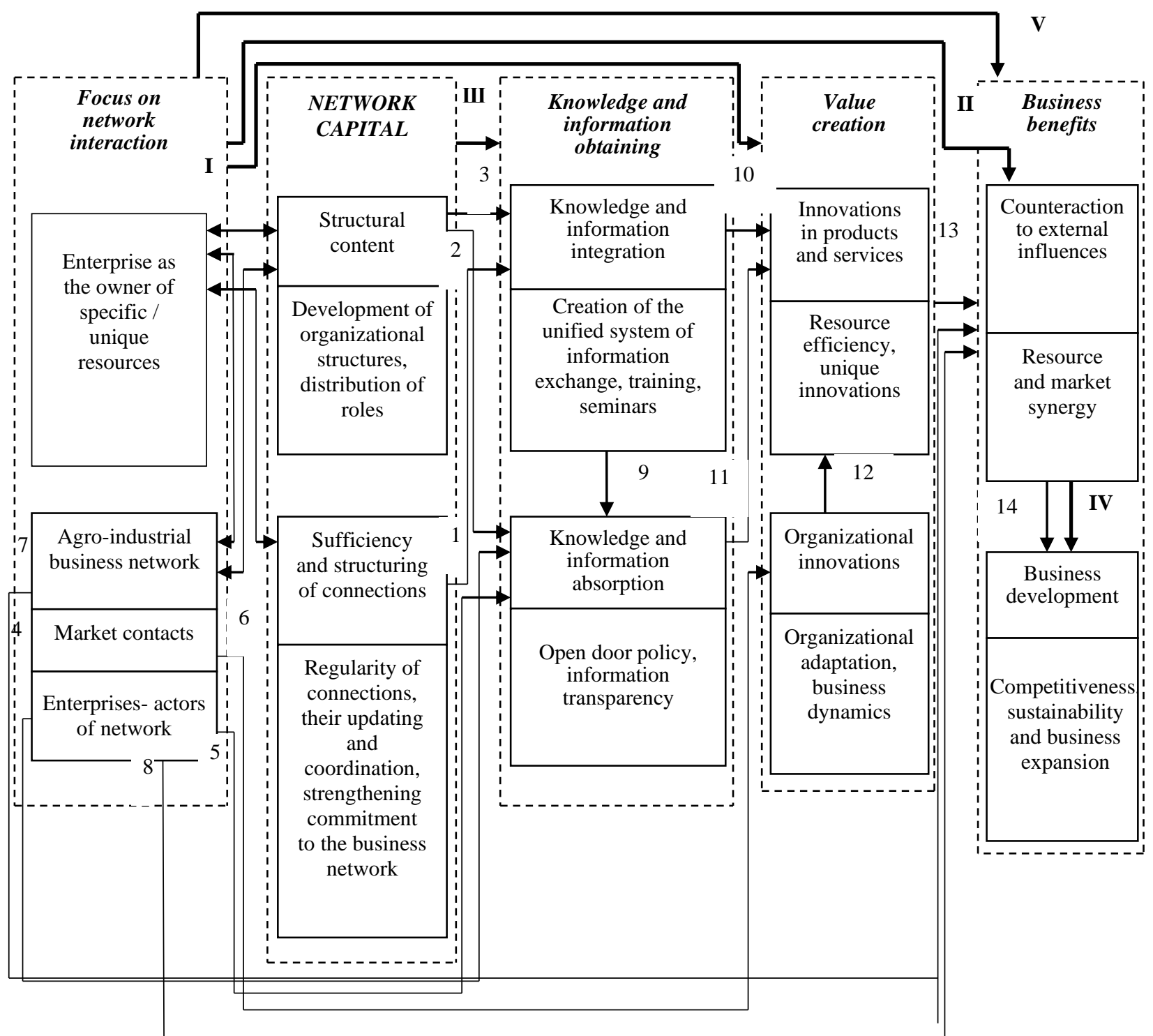

Fig. 2. Model of formation and use of network capital in the processes of the organizational interaction of participants of the strategic business partnership

Source: own development.

Inter-organizational connections between the separate stages of agro-industrial enterprises network interaction contain:

- "1" - sufficiency and rational structuring of enterprises-actors' connections in a business network influences on knowledge and information integration;

- "2" - structural content (adaptation of organizational structures and roles' division) affects the knowledge and information absorption by network participants;

- " 3 " - the network capital presence contributes to the formation of a stable flow of joint network intangible resources (knowledge, technology) in activity of each from the participating companies;

- "4" - network actors fill the network capital and provide other participants with access to the use of specific intangible resources and knowledge, which contributes to the joint and individual benefits from network interaction; 


\section{Agricultural and Resource Economics: International Scientific E-Journal http://are-journal.com}

- "5" - integration of specific knowledge (competencies) of participants has a positive effect on the external knowledge absorption (information, technology, etc.);

- "6" - marketability of inter-organizational relations in the business network contributes to the participants' organizational adaptations and business dynamics;

- "7" - inter-organizational interaction of partners, built on market relations in the agro-industrial business network, makes their adaptive and proactive capabilities stronger for counteracting external challenges;

- "8" - organizational innovations within the enterprises-actors have a positive effect on their ability for creation and realization of product innovations;

- "9" - creation of unified information system of business network increases the participants' network interaction efficiency and new knowledge absorption by them;

- "10" - integrating of knowledge/information resources inside the partnership has a positive effect on participants' ability to create new consumer values;

- "11" - absorption of external knowledge increases the enterprises-actors ability to coordinate their actions to adapt production systems to the conditions defined by the business network and market, taking into account the criteria of innovation;

- "12" - organizational innovations contribute to the resources efficient use (resource synergy) and the implementation of the innovations (market synergy) both individual participating enterprises and the business network as a whole;

- "13" - innovation and uniqueness of products and services offered to the market within the framework of strategic partnership, contributes to the participating enterprises' competitive potential growth;

- "14" - effective counteraction to external influences due to strengthening of a partners' network economic power, provides business development of each participant.

Each component of the agro-industrial enterprises' partnership is important for increasing business efficiency in the long run. However, the network connections highlighted in Fig. 2, depending on the format and specifics of the business network, will have different weights which can be deducted based on empirical research. And in the process of network connections managing (frequency of interaction, time, proximity and trust) and embedded resources (knowledge, skills, competencies) it is important to balance them - both in the context of maximizing the individual business processes consumer value and increasing business value in general.

Thus, value creation in the business network must be considered in the light of development of market opportunities of its participants - as a specific and one of the most important conditions for its preservation within the existing organizational shell. In this context, it should not be forgotten about the deterrents and incentives reaction to market changes (competitors' strategies for products and services, the state policy of incentives and restrictions change, capital and resources availability), feedback and suggestions on their products (services) from partners and through a network that defines a consistent position between business network participation, resources, and a strategy of creating shared value.

Therefore, network capital accumulates and implements in a partnership 


\section{Agricultural and Resource Economics: International Scientific E-Journal http://are-journal.com}

business network through network connections. However, the effectiveness of these processes is determined not only by the network structure but also by the nature of partnerships between enterprises-actors. After all, the inequality of such relations negatively affects the development of social capital, which does not meet the goals of strategic partnership. Such conclusions are confirmed by studies of J. Nahapiet and S. Ghoshal [39], who emphasize the duality of the enterprises' network interaction vectors. On the one hand, it is an increase of the internal resource opportunities due to organizational and structural (integration) factors, and on the other hand, it is an improvement in the quality of network relations for the efficient use of built-in, real and potential resources.

The latter lies in the motivational plane of partnerships, which is emphasized by P. Adler and S. Kwon [40, p. 19]. In particular, M. Mustafa and S. Chen are of the view that during the structuring of the network architecture it is necessary to outline the role of each participant in the integrated business system [41]. And this will help to reconcile their motivational preferences.

In our opinion, in a business network, these benefits should not be limited to the economic interests of individual actors (as follows from the main conclusions of the rational choice theory (H. Simon [42] H. Harsanai [43]), or behavioral economics, (R. Thaler, [44]), and considered from the standpoint of strategic perspective and overall benefit. If purely economic interests prevail, the partnership will not be able to develop, as participants may resort to opportunism in the process of organizational knowledge dissemination. However, the knowledge exchange within a strategic partnership is an important tool for achieving synergy and strengthening of competitive advantages, so motivation should extend to the processes of organizational knowledge development. Moreover, the interests' conciliation process may cover a wider range of stakeholders, such as local communities, regional authorities, logistics and trade companies and others. This will form the basis for the public benefit increasing from the strategic partnership network development in the agro-industry.

In general, participants in agro-industrial business networks are motivated to cooperate by various factors that are in the internal or external field of organizational interaction.

The main internal motives of network cooperation include:

1) the access to key resources for the formation of competitive advantages through the recombination of resources and processes, which allows finding additional opportunities for business development;

2) the increase in activities efficiency and profit growth through the development of organizational knowledge and business processes optimization, which allows reducing operating and transaction costs;

3 ) the business risks reduction through collective and consensual decisionmaking procedures, which increases their validity;

4) the increase of reliability level in the behaviour of partners in the implementation of network transactions, solidarity and support in case of individual 


\section{Agricultural and Resource Economics: International Scientific E-Journal}

http://are-journal.com

participants' problems.

The motives that are formed in the external space of organizational interaction are:

1) the opportunity to unite efforts to lobby important in terms of strategic prospects for the development of agriculture changes in the legislative field of the country;

2) increase access to investment resources for the development projects implementation;

3) reducing isolation from global development trends through involvement in global networks of economic activity.

We would like to emphasize that the business network has much wider opportunities to implement innovation and investment projects. When substantiating them, it is important to agree on the costs to be incurred by each participant (network actor) in the implementation of common for the network value creation processes. This will allow each actor to compare the costs with the possible benefits, and thus to compare the result with their own value structure and motivational benefits and thus decide to participate in the network. And this will create the basis for the formation of stable relations in the business network. Moreover, investment processes in Ukraine may intensify soon due to the adoption of the Law "On state support of investment projects with significant investments in Ukraine" № 3760, which entered into force on February 13, 2021 [45]. Especially since that, the law provides some benefits for strategic investors with investments of more than 20 billion euros, such investors could include investments that can be accumulated by members of the business network.

In our opinion, it is possible to balance the positions of actors in the network (their motivational advantages) based on the balance concept in game theory, formulated by Nobel Prize winner J. Nash [46], namely on the assumption that actors in a non-cooperative game will choose actions that can be defined by J. Nash as equilibrium. That is, those that will provide the desired for the network and acceptable to each network actor result; the latter will allow minimizing the cost of administering the joint activities of actors (primarily by eliminating the causes of opportunistic behaviour, which is manifested in organizational relations in the absence of trust between partners).

To increase the level of such trust (it means to shift the motivational preferences of actors from the position of maximizing their interests to the position of maximizing the results accumulated by the entire network) is possible by involving independent experts in the analysis of a joint business project. At the same time, all actors in the network must be sure that none of the experts has a vested interest in unreasonably defending the positions of individual actors. That is, no one will be able to manipulate the experts' opinion when making a final decision on the implementation of a joint business project.

Let's simulate this situation using the approaches to building models of partnership, which are described by A. Carida, M. Colurcio and M. Melia [47]. To do 
this, we assume that each of the experts formed their position (decided $-x_{i}$ ) in the form of an expert opinion, which contains the necessary justification for the strategy of the business project in terms of costs and revenues, and presented it for discussion in the expert environment: $s_{i} \in S_{i}$, where $i \in N=\{1,2, \ldots, n\}-$ set of experts. This conclusion opinion contains a plan $\left(\pi_{i}\right)$, based on a specific planning procedure. It is standard and predetermined, but the general algorithm can be implemented in a variety of tools, the choice of which depends on the subjective opinion of the expert $\left(r_{i}\right)$ (for example, a marketing plan to promote a product or a logistics support plan of the production process).

The combined actions of the experts are described as follows:

$x_{i}=\pi_{i}(s) \in X_{i} \subseteq \mathfrak{R}^{1}$, where $\pi: S \rightarrow X$ - planning procedure, $\pi_{i}: S \rightarrow X_{i}$, $i \in N$. Then the vector of published conclusions of all experts:

$$
s=\left(s_{1}, s_{2} \ldots s_{n}\right), \in S=\prod_{i \in N} S_{i}
$$

Together, they make it possible to determine the general vector of the network business strategy implementation plan:

$$
x=\left(x_{1}, x_{2} \ldots x_{n}\right), \in X=\prod_{i \in N} X_{i}
$$

The target function of the $i$-th expert, which reflects his interests and forms a position on the justification of the business project strategy, depends on his preferences $\left(r_{i}\right)$ in the choice of the planning procedure tools and reflects his subjective opinion on their feasibility

$$
f_{i}\left(x_{i}, r_{i}\right): X_{i} \times \mathfrak{R}^{1} \rightarrow \mathfrak{R}^{1}
$$

We'll consider that experts adhere to non-cooperative behaviour when choosing dominant or equilibrium strategies according to Nash. Thus, we'll accept that $s^{*}-$ a vector of strategies balanced by Nash experts:

$$
\forall i \in N, \forall s_{i} \in S_{i}, f_{i}\left(\pi_{i}\left(s_{-i}^{*} s_{i}^{*}\right), r_{i}\right) \geq f_{i}\left(\pi_{i}\left(s_{-i}^{*}, s_{i}\right), r_{i}\right) .
$$

In the general case, the equilibrium point depends on the vector of all experts' positions:

$$
s^{*}=s^{*}(r)=\left(s_{1}^{*}(r), s_{2}^{*}(r)_{2} \ldots s_{n}^{*}(r)\right)
$$

And if the vector of peak points of experts for any of their personal preferences $r \in \mathfrak{R}^{n}$ coincides with the vector of plans for the network business project implementation, which should be carried out according to the procedure (or mechanism) for this project $\left(h(r)=\pi\left(s^{*}(r)\right)\right.$, then we can say that there is a Nash equilibrium:

$$
\forall r \in \mathfrak{R}^{n}, \forall i \in N, \forall \tilde{r}_{i} \in \mathfrak{R}^{1} f_{i}\left(h_{i}(r), r_{i}\right) \geq f_{i}\left(h_{i}\left(r_{-i}, \tilde{r}_{i}\right), r_{i}\right)
$$




\section{Agricultural and Resource Economics: International Scientific E-Journal}

http://are-journal.com

Under these conditions, it can be argued that the expert assessment of the network's business project was carried out objectively, manipulations by experts who would defend their interests were not allowed.

Thus, the creation of conditions to prevent manipulation during the expert evaluation of joint business projects in the agro-industrial network will eliminate potential threats to the conflict of actors' interests in the distribution of costs and revenues. This means that it will form a motivational basis for mutually beneficial partnerships, thanks to which it is possible to achieve the effectiveness of network interaction.

Conclusions. Based on the results of our analysis of the dynamics and structural trends of the agricultural sector of Ukraine, a conclusion was made about their inconsistency with the "sustainable development" priorities. In particular, large agricultural holdings with sufficient investment potential prefer an extensive development path and focus on growing and exporting low-value-added industrial crops.

Medium and small agricultural enterprises usually enter into dependent relations with large ones, obeying their purchasing policy and only a small part of them implement modern business models in working with the market and choose niche strategies and develop organic farming. However, they mainly work for the domestic market. Lack of investment resources does not allow them to develop their export potential, using the terms of the association agreement with the EU in terms of dutyfree exports of products that have undergone industrial processing - because the acquisition of modern processing technologies requires significant investment. And the tax benefits that should encourage the development of processing industries, according to the adopted draft law № 3760, apply only to investment projects which value exceeds the equivalent of 20 million euros. This actually preserves the current state of affairs in the agricultural sector, creating preferences only for strategic investors.

We prove that positive changes can be achieved if we extend these benefits to projects implemented by business structures united in a business network. There are considered the conditions of development of agro-industrial business networks in Ukraine based on the integration of specific / unique resources which can provide resource and market synergy in the generation of new consumer values. We have proven that the effective functioning of a business network depends on its ability to create network capital. Given that the processes of its formation depend on the availability of potential participants unique / specific resources for the creation of new consumer values and their desire to share them, it is proposed to consider the term "network capital" in a broad and narrow sense; broadly - as a set of tangible and intangible benefits, defined in qualitative and quantitative indicators obtained from the business network; in the narrow sense - as a set of relations with enterprises interested in cooperation, formed on an institutional and contractual basis. This allows the initiators of a business network to determine, firstly, the main criteria by which to select participants (significant contribution to the creation of consumer 


\section{Agricultural and Resource Economics: International Scientific E-Journal}

http://are-journal.com

values), and secondly - how to achieve the effectiveness of their network interaction (forming a motivational basis for mutually beneficial relations). The paper systematizes such factors of advantages' formation that lie in the internal space of the business network and are formed as a result of processes occurring in the external environment.

Based on this, the order of formation of network capital is determined and a graphical model of realization of network interaction of enterprises within the framework of the strategic partnership is built; it describes the logical connections between network capital, creating value and efficiency of business network participants.

The effectiveness of networking depends on the confidence of actors in the mutual benefit of such cooperation, which takes into account their motivational preferences. We propose to coordinate the positions of actors in the network based on an independent expert evaluation to achieve Nash equilibrium. Creating conditions to prevent manipulation during the peer review of projects will eliminate potential threats of conflict of interest of actors in the distribution of costs and revenues, and the chosen vector of positions should provide the desired result for the network and be acceptable to each actor. This will increase the attractiveness of the strategic partnership and form the motivational basis for long-term and mutually beneficial partnerships.

\section{References}

1. Gupta, J. and Vegelin, C. (2016), Sustainable development goals and inclusive development. International Environmental Agreements: Politics, Law and Economics, vol. 16, no. 3, pp. 433-448. https://doi.org/10.1007/s10784-016-9323-z.

2. Mohd, H. A. and Norhidayah, S. (2016), Sustainable food production: insights of Malaysian halal small and medium sized enterprises. International Journal of Production Economics, vol. 181, part B, pp. 303-314. https://doi.org/10.1016/j.ijpe.2016.06.003.

3. Savickiene, J. and Miceikiene, A. (2018), Sustainable economic development assessment model for family farms. Agricultural Economics - Czech, vol. 64, pp. 527-535. https://doi.org/10.17221/310/2017-AGRICECON.

4. Ihnatenko, M. and Novak, N. (2018), Development of regional programs for the development of agrarian enterprises with organic production on the basis of the European and international experience. Baltic Journal of Economic Studies, vol. 4, no. 4, pp. 126-133. https://doi.org/10.30525/2256-0742/2018-4-4-126-133.

5. Kucher, A. (2019), Sustainable soil management in the formation of competitiveness of agricultural enterprises. Academic Publishing House «Talent», Plovdiv, Bulgaria. https://doi.org/10.13140/RG.2.2.19554.07366.

6. Kucher, L., Heldak, M. and Orlenko, A. (2018). Project management in organic agricultural production. Agricultural and Resource Economics, vol. 4, no. 3, pp. 104-128. https://doi.org/10.22004/ag.econ.281753.

7. Shevchenko, A. and Petrenko, O. (2020), Current state of micro and small agribusiness in Ukraine. Agricultural and Resource Economics, vol. 6, no. 1, 
pp. 146-160. https://doi.org/10.51599/are.2020.06.01.10.

8. Skydan, O., Nykolyuk, O., Pyvovar, P. and Martynchuk, I. (2020), Methodological approach to the evaluation of agricultural business system flexibility. Management Theory and Studies for Rural Business and Infrastructure Development, vol. 41, no. 4, pp. 444-462. https://doi.org/10.15544/mts.2019.36.

9. Carlisle, L., de Wit, M. M., DeLonge, M. S., Calo, A., Getz, C., Ory, J., Munden-Dixon, K., Galt, R., Melone, B., Knox, R., Iles, A. and Press, D. (2019), Securing the future of US agriculture: the case for investing in new entry sustainable farmers. Elementa: Science of the Anthropocene, vol. 7, 17. https://doi.org/10.1525/elementa.356.

10. Cardoso, J. F., Casarotto, F. N. and Marcon, C. (2020), Small business networks in the field of organic farming: strategies and management tools. Gestão \& Produção, vol. 27, is. 4, e4730. https://doi.org/10.1590/0104-530X4730-20.

11. Savarese, M., Chamberlain, K. and Gragna, G. (2020), Co-Creating value in sustainable and alternative food networks: the case of community supported agriculture in New Zealand. Sustainability, vol. 12(3), 1252. https://doi.org/10.3390/su12031252.

12. Sadovska, V., Axelson, L. E. and Mark-Herbert, C. (2020), Reviewing value creation in agriculture - a conceptual analysis and a new framework. Sustainability, vol. 12(12), 5021. https://doi.org/10.3390/su12125021.

13. Pasichnyk, Yu. (2020), Export of agricultural and food products of Ukraine: concept of prospects. Journal of European Economy, vol. 19, no. 2, pp. 247-264. https://doi.org/10.35774/jee2020.02.246.

14. Stadnyk, V., Krasovska, G., Pchelianska, G. and Holovchuk, Yu. (2021), Determinants of "green entrepreneurship" competitive strategies implementation in the agro-industrial sector of Ukraine. IOP Conference Series: Earth and Environmental Science. 8th International Scientific Conference on Sustainability in Energy and Environmental Science, 21-22 October 2020, vol. 628, 012032. IvanoFrankivsk, Ukraine. https://doi.org/10.1088/1755-1315/628/1/012032.

15. Stadnyk, V., Izhevskiy, P., Khrushch, N., Lysenko, S., Sokoliuk, G. and Tomalja, T. (2020), Strategic priorities of innovation and investment development of the Ukraine's economy industrial sector. CEUR Workshop Proceedings, vol. 2713, pp. 145-166, available at: http://ceur-ws.org/Vol-2713/paper12.pdf

16. The official site of State Statistics Service of Ukraine (2020), Production value of entities of large, medium, small and micro-entrepreneurship by type of economic activity in 2013-2019, available at: http://www.ukrstat.gov.ua/operativ/operativ2020/fin/pssg/ovpsg_vsmm_ek_2013_20 19_u.xlsx.

17. The official site of State Statistics Service of Ukraine (2020), Number of enterprises by type of economic activity with division into large, medium, small and micro enterprises in 2010-2019, available at: http://www.ukrstat.gov.ua/operativ/operativ2018/fin/pdp/pdp_u/kp_ek_vsmm_2010_ 2018_u.xlsx. 


\section{Agricultural and Resource Economics: International Scientific E-Journal}

http://are-journal.com

18. The official site of State Statistics Service of Ukraine (2020), Value added at factor costs of entities of large, medium, small and micro-entrepreneurship by type of economic activity in 2013-2019, available at: http://www.ukrstat.gov.ua/operativ/operativ2020/fin/pssg/dvvsg_vsmm_ek_2013_20 19_u.xlsx.

19. Agravery: agricultural news agency (2020), Shares of Ukrainian agricultural companies rose by an average of $10 \%$ in October, available at: https://agravery.com/uk/posts/show/akcii-ukrainskih-agrokompanij-u-zovtni-zrosli-vserednomu-na-10.

20. Maruniak, Ye., Lisovskyi, S., Holubtsov, O., Chekhnii, V., Farion, Yu. and Amosov, M. (2021), Doslidzhennia vplyvu kontsentratsii silskohospodarskykh zemel na dovkillia ta suspilstvo $v$ Ukraini [Study of the impact of agricultural land concentration on the environment and society in Ukraine], Kyiv, Ukraine.

21. The official site of State Statistics Service of Ukraine (2019), Labor costs of enterprises by type of economic activity with a division into large, medium, small and micro enterprises, available at: http://www.ukrstat.gov.ua/operativ/operativ2013/fin/kp_ed/kp_ed_u/vopp_ed_u_2019.htm.

22. The official site of State Statistics Service of Ukraine (2019), Number of employees in enterprises by type of economic activity with a division into large, medium, small and micro enterprises, available at: http://www.ukrstat.gov.ua/operativ/operativ2013/fin/kp_ed/kp_ed_u/kzp_ed_u_2019. htm.

23. The Verkhovna Rada of Ukraine (2021), The Law of Ukraine "On amendments to the Tax Code of Ukraine concerning the value added tax rate on transactions for the supply of certain types of agricultural products», available at: https://zakon.rada.gov.ua/laws/show/1115-20\#Text.

24. Agropolit (2021), Reducing the VAT rate for the agricultural sector to $14 \%$ : the fight against "twists" or a preference of \$ 80-120 million for sunflower processor, available at: https://agropolit.com/spetsproekty/859-znijennya-stavki-pdv-dlyaagrosektoru-do-14-borotba-zi-skrutkami-chi-preferentsiya-v-80-120-mlnpererobniku-sonyashniku.

25. The Cabinet of Ministers of Ukraine (2021), Resolution of the Cabinet of Ministers of Ukraine "On approval of the National Economic Strategy for the period up to 2030", available at: https://www.kmu.gov.ua/npas/pro-zatverdzhennyanacionalnoyi-eko-a179.

26. Official Facebook page of the Sustainable Development Agency ASTAR, available at: https://www.facebook.com/astar.age.

27. Official site NGO "Ukrainian Nut Association", available at: https://www.gardens-nuts.com.ua/ru/partnery/24-ukrainskaya-orekhovayaassotsiatsiya.html

28. Official site of Association "Yahidnytstvo Ukrainy", available at: https://uaberries.com.

29. Official Facebook page of the first national agrarian cooperative 
organization, available at: https://www.facebook.com/pnak.com.ua.

30. Stadnyk, V., Pchelianska, G., Holovchuk, Yu. and Dybchuk, L. (2020), The concept of marketing of balanced development and features of its implementation in the food market. Agricultural and Resource Economics, vol. 6, no. 3, pp. 80-95. https://doi.org/10.51599/are.2020.06.03.

31. Perechuda, K. and Chomiak-Orsa, I. (2013), The positioning of relational capital in management models. Zarzadzanie i Finanse, vol. 11, no. 4, pp. 293-307.

32. Wallace, E. (2006), Fares to friends. How to develop outstanding business relationship, 1st ed. The Relational Capital Group, Inc.

33. Bourdieu, P. (1986), The forms of capital In Handbook of theory and research for the sociology of education, ed. by J. G. Richardson. Westport, CT: Greenwood, New York, USA.

34. Coleman, J. S. (1988), Social capital in the creation of human capital. The American Journal of Sociology, vol.94, pp.95-120, available at: https://www.jstor.org/stable/2780243.

35. Kolot, A. M. (2010), Sotsialno-trudova sfera: stan vidnosyn, novi vyklyky, tendentsii rozvytku [The social and labor issues: state relations, new challenges and trends], KNEU, Kyiv, Ukraine.

36. Camagni, R. (2009), Territorial capital and regional development In Handbook of Regional Growth and Development Theories, eds R. Capello and P. Nijkamp, Edward Elgar Publishing Limited, Cheltenham, UK; Northampton, MA, USA, pp. 118-132, available at: https://is.gd/RPw1p9. 20.

37. Czakon, W. (2010), Hipoteza bliskości. Przeglad Organizacji, no. 9, pp. 16-

38. De Wit, B. and Meyer, R. (2014), Strategy synthesis, managing strategy paradoxes to create competitive advantage, 4 th ed. Cengage Learning, London, UK.

39. Nahapiet, J. and Ghoshal, S. (1998), Social capital, intellectual capital and the organizational advantage. The Academy of Management Review, vol. 23, no. 2, pp. 242-266. https://doi.org/10.5465/amr.1998.533225.

40. Adler, P. S. and Kwon, S. (2002), Social capital: prospects for a new concept. The Academy of Management Review, vol. 27, no. 1, pp. 17-40. https://doi.org/10.2307/4134367.

41. Mustafa, M. and Chen, S. (2010), The strength of family networks in transnational immigrant entrepreneurship. Thunderbird International Business Review, vol. 52, is. 2, pp. 97-106. https://doi.org/10.1002/tie.20317.

42. Simon, H. A. (1955) A behavioural model of rational choice. The Quarterely Journal of Economics, vol. 69, is. 1, pp. 99-118.

43. Harsanyi, H. (1977), Rational behaviour and bargaining equilibrium in games and social situations. Cambridge University Press, Cambridge, UK.

44. Thaler, R. H. (2017), Behavioral economics. Journal of Political Economy, vol. 125 , is. 6 , pp. $1799-1805$.

45. The Verkhovna Rada of Ukraine (2020), The Law of Ukraine "On state support of investment projects with significant investments in Ukraine", available at: 
https://zakon.rada.gov.ua/laws/show/1116-20\#Text.

46. Nash, J. (1951), Non-cooperative Games. Annals of Mathematics, vol. 54, no. 2, pp. 286-295. https://doi.org/10.2307/1969529.

47. Carida, A., Colurcio, M. and Melia, M. (2015), Designing a collaborative business model for SMEs. Sinergie. Italian journal of management, vol. 33, no. 98, pp. 233-253. https://doi.org/10.7433/s98.2015.14.

Citation:

Стиль-ДСТУ:

Stadnyk V., Krasovska G., Izhevskiy P., Tomalia T., Khomych L., Matveev P. Motivational aspects of development of strategic network partnership in the agroindustrial complex. Agricultural and Resource Economics. 2021. Vol. 7. No. 2. Pp. 77-101. https://doi.org/10.51599/are.2021.07.02.05.

Style-APA:

Stadnyk, V., Krasovska, G., Izhevskiy, P., Tomalia, T., Khomych, L. and Matveev, P. (2021), Motivational aspects of development of strategic network partnership in the agro-industrial complex. Agricultural and Resource Economics, vol. 7, no. 2, pp. 77-101. https://doi.org/10.51599/are.2021.07.02.05. 